\title{
Co jest źródłem satysfakcji gracza? 0 kluczowej roli wymiany autystycznej w grach komputerowych
}

What is the origin of gamer satisfaction?

The key role of autistic exchange in video games

\section{Łukasz Winnicki}

Uniwersytet Ekonomiczny w Krakowie uwinnicki@gmail.com | ORCID: 0000-0003-1058-0662

\begin{abstract}
Video games phenomena is something entirely new in mankind history. Yet it haven't preceded our nature so it still should be readily explained by some basic terms. In this case the author suggests that the exchange is the fundament of players action and the source of their satisfaction. Using Mises (economist's), Homans (sociologist's) and positive psychologists' (character strengths) legacy, deduction process takes place and an Internet questionnaire is being conducted. Results obtained from 669 players are analysed and used to verify the main hypothesis of the text and - at the end - to affirm it.
\end{abstract}

Keywords: video game, exchange, George Homans, Ludwig von Mises, satisfaction, strengths of character 



\section{Wstęp}

Gry komputerowe przyciągają coraz więcej osób - było ich w 2017 roku co najmniej 2,2 mld na około 7,6 mld ogółu ludzi (czyli aż 29\% populacji globu). Ekspansja rozrywki interaktywnej będzie trwać nadal choćby z powodu postępującej globalizacji, rozwoju gospodarczego biedniejszych państw czy odkrywania nowych zastosowań gier komputerowych. Jednak główny cel ich istnienia - bawienie, dostarczanie satysfakcji - najprawdopodobniej się nie zmieni. Dlatego warto zbadać, uchwycić źródło tego oddziaływania, pozytywnego w odbiorze. W pracy dyplomowej pisanej na Uniwersytecie Ekonomicznym w Krakowie autor chciał sprawdzić, czy aby to nie naturalna dla ludzi skłonność do wymiany stoi za każdym aktem grania - a jeśli tak, to z jakiego powodu (Winnicki, 2017) ${ }^{1}$. Dlatego też została sformułowana hipoteza badawcza mówiąca, iż „to wymiana jest tym, czego gracze najbardziej oczekują od gry komputerowej". Na potrzeby niniejszego artykułu zdecydowałem się ją przeformułować w następujący sposób:

Gry komputerowe są oparte na zjawisku wymiany, co skutkuje dostarczaniem graczom satysfakcji.

Aby potwierdzić powyższą hipotezę, należałoby pozytywnie odpowiedzieć co najmniej na dwa pytania badawcze. Po pierwsze: czy zjawisko gier komputerowych można w ogóle opisywać za pomocą zjawiska wymiany? Po drugie: czy ta (potencjalna) wymiana rzeczywiście dostarcza graczom satysfakcji (i dlaczego)? W kolejności wyznaczonej przez te pytania postaram się w niniejszym artykule zweryfikować postawioną hipotezę.

\section{Wymiana}

Jak można rozumieć wymianę? Najczęściej zakłada się, że do zaistnienia jej najprostszej formy potrzebne są co najmniej dwie osoby, które dobrowolnie wymieniają jedno dobro na drugie. Te dobra mogą mieć charakter najróżniejszych towarów i usług. Taka wymiana stoi w centrum zainteresowania ekonomii. Jednak spora część wymian nie jest tak wzorcowa, jak

\footnotetext{
${ }^{1}$ Jest to jedyne odwołanie do pracy dyplomowej autora, ale cały niniejszy artykuł na niej bazuje.
} 
to zostało przedstawione w definicji. Nie kwestionuję tutaj założenia o ich dobrowolności (które nierzadko zostaje naruszone - np. w wyniku użycia przemocy, samej groźby lub na skutek uzależnienia), lecz to o konieczności uczestnictwa w nich co najmniej dwóch osób. Wymiany niespełniające tego warunku istnieją, są dosyć powszechne i noszą nazwę wymian autystycznych - w opozycji do tych międzyludzkich.

Wymiana autystyczna zachodzi między człowiekiem a samym środowiskiem i ma charakter przyczynowo-skutkowy. Jest przede wszystkim reakcją środowiska na działanie lub jego zaniechanie przez człowieka (Mises, 2011, s. 201). Przykład takiej wymiany stanowi sytuacja, w której myśliwy poluje na zwierzynę i tym samym wymienia swój wypoczynek i nabój na żywność. Ten rodzaj wymiany można odnieść nie tylko do środowiska naturalnego, ale i do sztucznego - wirtualnego, coraz szerzej dostępnego ludzkości. Jeżeli zaś oddziaływanie zachodzące między graczem a światem wirtualnym jest $w$ istocie wymianą, to będzie można je opisać za pomocą ugruntowanej w nauce teorii wymiany, a nawet orzec o jej konsekwencjach - czy rzeczywiście dochodzi do zamiany jednego dobra na drugie i jakie należy określić to, które gracz otrzymuje.

\section{Ogólna teoria wymiany}

Dziedziną nauk społecznych, w obrębie której istnieje pewna ogólna teoria wymiany, a która może okazać się pomocna przy badaniu graczy komputerowych, jest socjologia. Socjologiczna teoria wymiany nie odnosi się tylko do wymiany czysto międzyludzkiej. Chcąc bowiem wyjaśnić zjawisko A, trzeba przeto założyć - pisze George Homans, współautor teorii wymiany - że składające się na nie zachowania jednostek są w jakiś sposób nagradzane przez „system”, który w ten sposób je wzmacnia (Szacki, 2007, s. 839-840). Homans i inni naukowcy zajmujący się teorią wymiany mają skłonność do skupiania się na zjawiskach elementarnych - co wydaje się bardzo przydatne do bliższego zbadania zjawiska gier komputerowych oraz do korzystania z dorobku antropologii i socjologii w celu tworzenia twierdzeń o wysokim stopniu ogólności (tamże). Dzięki tym twierdzeniom, które zostaną później zaprezentowane, możliwa będzie weryfikacja poprawności hipotezy badawczej postawionej na początku. 
W swojej teorii Homans zakłada istnienie natury ludzkiej, czyli czegoś uniwersalnego dla każdego człowieka, czegoś wspólnego nam wszystkim. Czyni to również Adam Smith, zwany ojcem ekonomii, w swoim najsłynniejszym dziele, pt. Badania nad natura i przyczynami bogactwa narodów. Twierdzi, że następstwem istnienia ludzkiej natury jest obserwowalna skłonność do wymiany, handlu i zamiany jednej rzeczy na drugą (1776). Skoro natura ludzka jest czymś zupełnie elementarnym oraz niezaprzeczalnie ludzkim, to i zdefiniowanie jednego z jej składników jako skłonności do wymiany daje asumpt do dostrzegania fundamentalnej roli tej skłonności w każdym aspekcie życia. Dlatego też podjąłem próbę adaptacji socjologicznej teorii wymiany do jednego z wielu wycinków aktywności ludzkiej, jaką jest rozrywka interaktywna.

George Homans następująco formułuje poszczególne twierdzenia swojej ogólnej teorii wymiany:

Twierdzenie o sukcesie. TWIERDZENIE 1. Im częściej działanie jednostki jest nagradzane, tym bardziej jest prawdopodobne podjęcie przez nią tego działania.

Twierdzenie o bodźcu. TWIERDZENIE 2. Jeżeli w przeszłości wystąpienie określonego bodźca lub zespołu bodźców było okolicznością, w której działanie jednostki zostało nagrodzone, to im bardziej aktualny bodziec podobny jest do tych występujących w przeszłości, tym bardziej jest prawdopodobne, że jednostka podejmie to lub podobne działanie.

Twierdzenie o wartości. TWIERDZENIE 3. Im bardziej działanie jest dla jednostki wartościowe, tym bardziej jest prawdopodobne, że będzie ona przejawiała to działanie. Twierdzenie o deprywacji-nasyceniu. TWIERDZENIE 4. Im częściej w niedawnej przeszłości jednostka otrzymywała określoną nagrodę, tym mniej wartościowa staje się dla niej każda następna jednostka tej nagrody.

Twierdzenie o frustracji-agresji. TWIERDZENIE 5. Jeżeli działanie jednostki nie doprowadza do otrzymania oczekiwanej nagrody lub jednostka ta otrzyma karę, której się nie spodziewała, zareaguje gniewem, a w gniewie rezultaty zachowania agresywnego będą miały wartość nagradzającą (1992, s. 177-180).

\section{Podmiot badania}

W celu sprawdzenia tych przypuszczeń przeprowadziłem badanie kwestionariuszowe za pośrednictwem portalu Facebook przy pomocy 
Formularza Google. Badanie bazowało na doświadczeniach graczy $\mathrm{z}$ gatunkiem cRPG ( $\mathrm{z}$ ang. computer Role-Playing Game - komputerowa gra fabularna) i jego licznymi reprezentantami z czterech serii: Gothic, The Elder Scrolls, Wiedźmin i Mass Effect. Cechą charakterystyczną wszystkich tytułów jest rozgrywka jednoosobowa, co miało za zadanie niwelować możliwość odnoszenia przez graczy swoich odpowiedzi do typowych wymian międzyludzkich na rzecz poszukiwanej wymiany autystycznej. Opierając się na tych produkcjach, ankietowani odpowiadali w sumie na kilkadziesiąt pytań, które przede wszystkim skupiały się na ocenie poziomu imersji, grywalności i czerpanej w związku z tym satysfakcji $\mathrm{z}$ wybranych produkcji. Poniżej przedstawiam tabelę zawierającą skrócone informacje dotyczące samego badania i grupy badanej.

Tabela 1. Statystyki badania kwestionariuszowego oceniającego rolę wymiany w grach komputerowych w Polsce w liczbach

\begin{tabular}{|c|c|c|c|c|c|c|c|}
\hline $\begin{array}{l}\text { Termin } \\
\text { realizacji }\end{array}$ & $\begin{array}{l}\text { Liczba } \\
\text { ankietowanych }\end{array}$ & \multicolumn{2}{|c|}{ Płeć badanych } & \multicolumn{4}{|c|}{ Wiek badanych } \\
\hline 2-11 paź- & \multirow{2}{*}{669 osób ${ }^{2}$} & M & K & poniżej 16 & $16-18$ & $19-25$ & powyżej 25 \\
\hline 2016 roku & & $93,3 \%$ & $6,7 \%$ & $27,7 \%$ & $50,7 \%$ & $19,5 \%$ & $2,1 \%$ \\
\hline \multicolumn{4}{|c|}{$\begin{array}{l}\text { Czas spędzany w wirtualnym świecie gier } \\
\text { (tygodniowo) }\end{array}$} & \multicolumn{4}{|c|}{ Wykształcenie } \\
\hline $\begin{array}{l}\text { poniżej } \\
2 \mathrm{~h}\end{array}$ & $2-10 \mathrm{~h}$ & $\begin{array}{c}10- \\
20 \mathrm{~h}\end{array}$ & $\begin{array}{c}\text { po- } \\
\text { wyżej } \\
20 \text { h }\end{array}$ & $\begin{array}{l}\text { podsta- } \\
\text { wowe }\end{array}$ & $\begin{array}{l}\text { gimna- } \\
\text { zjalne }\end{array}$ & średnie & wyższe \\
\hline $3,7 \%$ & $39,3 \%$ & $30,1 \%$ & $26,8 \%$ & $6,2 \%$ & $61,1 \%$ & $29,3 \%^{3}$ & $3,5 \%$ \\
\hline
\end{tabular}

Grupa badana składa się głównie z widzów youtubera Patryka „Roja” Rojewskiego skupionych w grupie Tarczownicy Roja. Link do kwestionariusza został udostępniony tej społeczności i osoby chętne dobrowolnie

2 Podana liczba obejmuje wszystkie osoby, które zdecydowały się na udział w badaniu internetowym; realna liczba osób, które z pewną dozą powagi odpowiedziały na wszystkie pytania, mieści się w przedziale 631-668.

3 Ze względów praktycznych doliczone zostały tutaj osoby deklarujące wykształcenie zawodowe $(5,4 \%)$ oraz brak wykształcenia $(0,6 \%)$. 
go wypełniały. Zdecydowana większość ankietowanych to osoby młode, mężczyźni (93,3\%), dopiero wkraczające w dorosłe życie (78,4\% to osoby w wieku 18 lat i młodsze), z wykształceniem typowym dla swojego przedziału wiekowego, grające w gry komputerowe co najmniej po kilkakilkanaście godzin tygodniowo. Zatem większość badanych należy do najnowszego pokolenia - Z, od wczesnej młodości będącego częścią świata cyfrowego (Walków, 2017).

\section{Wyniki badania wymiany}

Opisanie zjawiska gier komputerowych za pomocą teorii wymiany stanowi pierwszy z dwóch głównych celów przeprowadzonego badania. Postanowiłem sprawdzić, czy doświadczenie graczy komputerowych jest zgodne z czterema ${ }^{4}$ twierdzeniami Homansa: o sukcesie, o bodźcu, o wartości i o frustracji-agresji. W tym celu postawiłem następujące pytania bezpośrednio związane z każdym z tych twierdzeń i uzyskałem poniżej zaprezentowane odpowiedzi. Co ciekawe, mogą one być interpretowane także na korzyść twierdzeń, których pozornie nie dotyczyły, dzięki czemu pytanie odnoszące się do twierdzenia drugiego będzie można pominąć.

4 Twierdzenie 4 - o deprywacji-nasyceniu - zostało celowo pominięte. Wedle niego każda kolejna jednostka danej nagrody jest mniej wartościowa od poprzedniej. Były ku temu trzy główne powody. Po pierwsze, gry, w których jasno widoczne jest działanie twierdzenia o deprywacji-nasyceniu, byłyby monotonne i nieatrakcyjne. Cechowałaby je niska grywalność spowodowana zniechęceniem pojawiającym się u gracza trakcie rozgrywki. Gry wybrane do badania są bardzo wysoko oceniane, więc stanowią tu nieodpowiedni punkt odniesienia, bo mechanizm nagradzania został tam najpewniej świetnie skonstruowany. Po drugie: już ekonomiczne prawo malejącej użyteczności krańcowej doskonale tłumaczy na poziomie bardziej ogólnym czwarte twierdzenie Homansa - korzyść krańcowa każdej kolejnej konsumowanej jednostki danego dobra jest mniejsza od korzyści z poprzednio skonsumowanej jednostki, ergo gracz wyżej ceni jedną godzinę grania niż żadną (na początku przyrost satysfakcji jest największy), a każda kolejna godzina wydaje się mniej cenna od poprzedniej (ze względu na coraz większe częściowe zaspokojenie potrzeby zabawy). Po trzecie, udzielenie przez graczy odpowiedzi na pytanie typu: „Czy po pierwszej godzinie grania odczułaś/-eś większą satysfakcję niż po drugiej?”, mogłoby być kłopotliwe ze względu na, z jednej strony, abstrakcyjność tego pytania, utrudniającą zdroworozsądkowy osąd, a z drugiej, na wymóg dokonania pomiaru celem sformułowania rzetelnej odpowiedzi. 


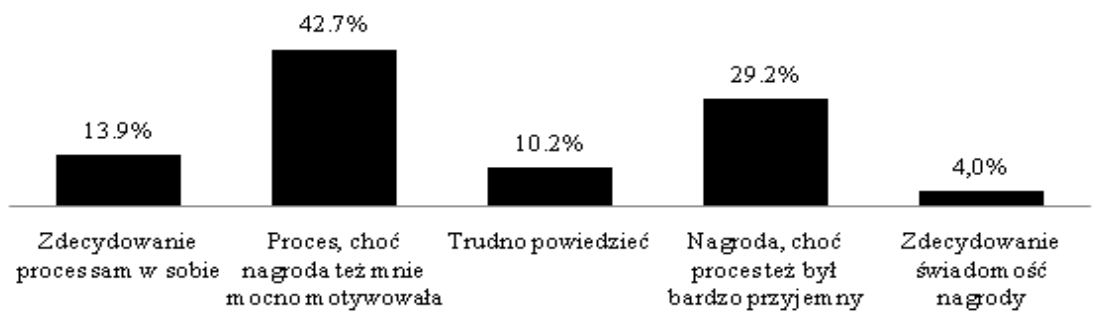

Wykres 1. Odpowiedzi na pytanie dot. twierdzenia 1 - o sukcesie: „Czy świadomość czekającej Cię nagrody po wykonaniu zadania w grze była dla Ciebie motywująca, czy też sam proces wykonywania zadania stanowił nagrodę?"

Twierdzenie 1 - o sukcesie - mówi, że nagradzanie działania skutkuje zwiększeniem częstotliwości jego występowania. Potwierdzają to niektóre z odpowiedzi: w sumie $33,2 \%(29,2 \%+4 \%)$ graczy potwierdza istotność motywacji wynikającej ze zdobywania wirtualnych nagród, np. w postaci złota, nowej broni czy awansu w hierarchii społecznej.

Jednakże większość, bo w sumie 56,6\% ankietowanych (13,9\%+42,7\%) jako ważniejszy lub jedyny czynnik motywujący wskazało proces sam w sobie, co doskonale koresponduje z trzecim twierdzeniem Homansa - o wartości w tym wypadku odnoszącej się do procesu wykonywania zadania. Ta bowiem grupa uważa działanie, którym jest granie, za wartościowe samo w sobie ${ }^{5}$, co w ostatecznym rozrachunku skutkuje wielo(set)godzinną rozgrywkąa.

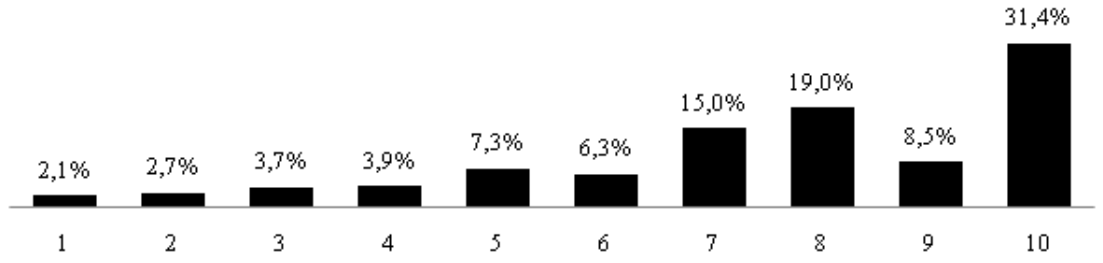

Wykres 2. Pytanie dot. twierdzenia 3 - o wartości: „Czy często zdarzało Ci się błądzić po świecie wirtualnym bez wyraźnego celu?”

5 Próba wyjaśnienia powodów jego wysokiej wartościowości zostanie podjęta w drugiej części niniejszego artykułu.

6 Pozostałym 10.2\% trudno było odpowiedzieć, co ich motywuje. Najczęściej w uzasadnieniu wskazywali oni na obydwa elementy - nagrodę i proces - po równo, na brak jasnej zasady lub skłaniali się ku procesowi. 
Odpowiedzi na to i wszystkie następne pytania, jakich udzielano w skali od 1 do 10, były oznaczone od „Nigdy” do „Bardzo często”. Zdecydowanej większości osób - jak widać na wykresie 2 - zdarzało się błądzić po świecie wirtualnym bez celu. Mimo braku wyraźnego powodu dokonywano tego bardzo często, co oznacza konieczność istnienia pewnych motywacji kierujących działającymi.

Po pierwsze, dotyczyły one wymiany własnego czasu na satysfakcjonującą aktywność, co zgadza się z przywołanym już trzecim twierdzeniem Homansa - o wartości - ponieważ „błądzenie bez wyraźnego celu” było czynnością chętnie powtarzaną, nagrodą samą w sobie, a zatem działaniem wartościowym w oczach graczy. Oto najczęstsze uzasadnienia:

- chęć eksploracji, czerpania przyjemności ze sprawdzania różnych zakamarków;

- przyjemność czerpana z podziwiania piękna i romantyzmu wirtualnego świata;

- potrzeba relaksu i urozmaicenia czasu.

Po drugie, działanie bez wyraźnego celu, o które byli pytani ankietowani, w istocie miało swój cel, choć był on traktowany jako niewyraźny, niepewny. Koresponduje to $\mathrm{z}$ drugim twierdzeniem Homansa - o bodźcu ponieważ w trakcie takich „bezinteresownych” eksploracji gracz mógł coś zyskać. Wymieniano tu najczęściej:

- odnalezienie misji pobocznej;

- lepsze poznanie świata przedstawionego, jego historii;

- dowiedzenie się, co twórcy gry przygotowali dla gracza - co jest bezpośrednim wskazaniem na drugi podmiot wymiany dokonywanej przez graczy (zamiast, jak zazwyczaj, na jej przedmiot);

- znajdowanie tzw. znajdziek lub easter eggów?

Pytania i wyniki trzech badań ankietowych przedstawionych na kolejnej stronie wprost nawiązują do piątego twierdzenia Homansa - o frustracji-agresji - a dokładniej do każdego z jego trzech elementów. Właśnie ze względu na tę trójczłonowość sformułowałem aż trzy pytania - w celu

\footnotetext{
${ }^{7}$ Easter egg (z ang. wielkanocne jajo), czyli treść ukryta przed graczem, wymagająca pewnego wysiłku i/lub zbiegu okoliczności celem jej odnalezienia, często humorystycznie nawiązująca do treści np. innych gier czy produktów kultury.
} 
kompleksowej oceny możliwości aplikacji piątego twierdzenia do zjawiska gier komputerowych.

Wykres pierwszy dotyczy prostego określenia częstotliwości wpadania w gniew na skutek otrzymania kary lub braku oczekiwanej nagrody.

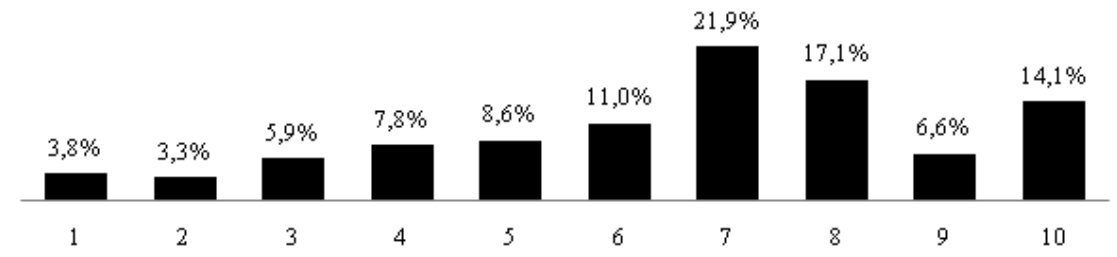

Wykres 3.1. Pytanie dot. twierdzenia 5 - o frustracji-agresji: „Czy miałeś/-aś sytuację, w której w trakcie gry odczułeś/-aś gniew, złość?”

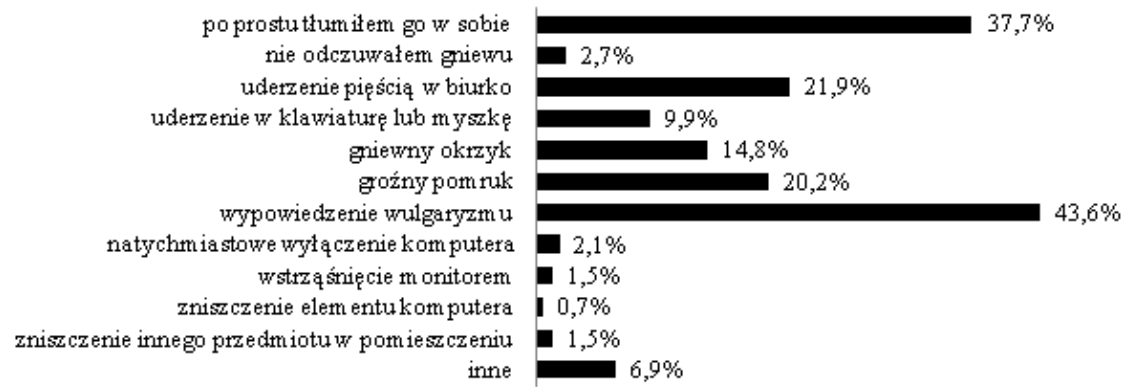

Wykres 3.2. Pytanie dot. twierdzenia 5 - o frustracji-agresji: „W jaki sposób zdarzyło Ci się wyładować powstały gniew?" (możliwość wielokrotnego wyboru)

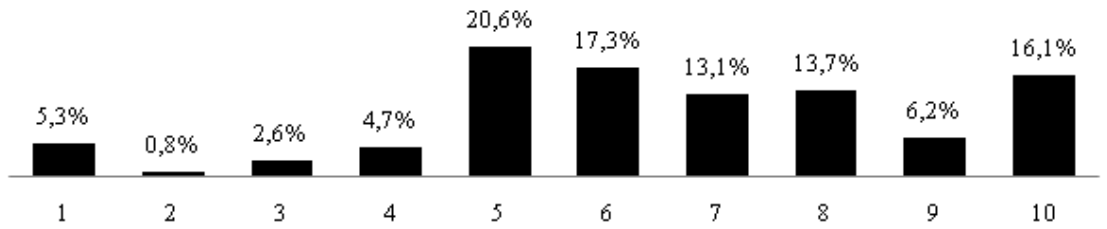

Wykres 3.3. Pytanie dot. twierdzenia 5 - o frustracji-agresji: „Czy czułeś się lepiej po wyładowaniu swojej agresji? (proszę, daj 5, jeśli Cię to nie dotyczy)" 
Widać, że 70,7\% ankietowanych wskazało wartości 6 i większe. Wyniki zgromadzone na podstawie odpowiedzi na to pytanie pozwalają sformułować wniosek, że gry z powodu niepomyślnego obrotu wirtualnych zdarzeń często wywołują w graczach negatywne emocje.

Celem pytania, którego dotyczy wykres drugi, jest sprawdzenie, czy gniew skutkuje zachowaniami agresywnymi. Ich wystąpienie jest konieczne, by móc w ogóle rozważać zastosowanie piątego twierdzenia Homansa. Gniew, który powstał w wyniku czynności grania w gry komputerowe, był różnie traktowany przez graczy, jak widać na wykresie 3.2, co pozwala jednoznacznie potwierdzić występowanie zachowań agresywnych; tylko $2,7 \%$ badanych nie odczuwało gniewu. Co ciekawe, we wspomnianej grupie osób, które wybrały odpowiedź „inne” (6,9\%) pojawiły się takie przykłady, jak wyjście na papierosa, zmiana gry czy wykonywanie ćwiczeń fizycznych.

Wykres 3.3 prezentuje wyniki dotyczące odpowiedzi na pytanie o samopoczucie graczy po wyładowaniu własnej agresji i jest sprawdzeniem, czy rzeczywiście, zgodnie z piątym twierdzeniem, występujące „w gniewie rezultaty zachowania agresywnego będą miały wartość nagradzającą”. Spośród ankietowanych $66,2 \%$ wskazało wartości 6 i wyższe, gdzie 10 było oznaczone jako „Zdecydowanie tak”, a 1 - „Zdecydowanie nie”. Takie wyniki pozwalają wysnuć wniosek, iż gracze generalnie czują się lepiej po wyładowaniu swojej agresji i ma to dla nich wartość nagradzającą.

W analizie odpowiedzi na zadane graczom powyższe trzy pytania dotyczące twierdzenia o frustracji-agresji udało mi się odkryć pewien ciąg przyczynowo-skutkowy. Otóż gracze w swoich odpowiedziach deklarowali występowanie sytuacji, w których wpadali w gniew, a następnie nierzadko go wyładowywali na różne sposoby, co z kolei skutkowało polepszeniem się ich stanu psychicznego. Oznacza to, że piąte twierdzenie Homansa również znajduje swoje zastosowanie do opisu reakcji graczy komputerowych.

\section{Wnioski z badania wymiany}

Po przeanalizowaniu odpowiedzi pytania na postawione wypełniającym kwestionariusz można stwierdzić, że ogólna teoria wymiany Homansa jest jak najbardziej aplikowalna do gier komputerowych. Oznacza to, że zjawisko wymiany (szczególnie autystycznej) szeroko występuje 
w doświadczaniu rozrywki interaktywnej. Nie pozwala to jednak jeszcze pozytywnie zweryfikować hipotezy niniejszego artykułu, ponieważ gracze w badaniu nie wyrażali jakiegokolwiek pożądania wobec wymiany, a przynajmniej nie bezpośrednio.

Twierdzenie pierwsze - o nagrodzie - zostało bezpośrednio potwierdzone przez wskazanie jej jako głównego czynnika motywującego w grze przez 32,2\% badanych. Twierdzenie drugie - o bodźcu - zweryfikowało to, że gracze jako jeden $\mathrm{z}$ dwóch głównych powodów, dla których lubią błądzić swoją postacią po wirtualnym świecie gry, podali możliwość „znalezienia czegoś". Twierdzenie trzecie - o wartości - zostało potwierdzone podwójnie: poprzez wskazanie $54,4 \%$ ankietowanych procesu samego w sobie jako głównej zachęty do działania; oraz gdy ankietowani wymienili jako przyczynę swojego błądzenia po grze radość z czerpania przyjemności zmysłowych. Twierdzenie czwarte - o deprywacji-nasyceniu - także znalazło zastosowanie w przypadku elektronicznej rozrywki. Najbardziej dobitne potwierdzenie zyskało twierdzenie piąte - o frustracji-agresji gdy zdecydowana większość graczy zaznaczyła swoje sposoby wyładowywania gniewu związanego z grami. Wnioski z analizy ostatniej części badania są takie, że wszystkie pięć twierdzeń Homansa sprawdza się w przypadku uczestników gier komputerowych.

\section{Atrakcyjność gier komputerowych}

Nieliczna grupa graczy, którzy poddali się badaniu kwestionariuszowemu, wskazała, co takiego zachęciło ich do wejścia w świat wirtualnej rozrywki i pozostania tam dłużej ${ }^{8}$. Wymienili oni takie przyczyny jak: chęć doświadczenia ciekawie opowiadanych przez gry porywających historii, ucieczka od rzeczywistości, odstresowujący wpływ rozgrywki, możliwość bycia kimś innym, lepszym, czy nieskrępowaną wolność. Nie wnikając w te specyficzne motywacje, ich powód działania można, jak w przypadku każdego

8 Co ciekawe, zrobili to podczas uzasadniania swojej aprobaty dla stwierdzenia: „Granie w gry komputerowe pozytywnie wpłynęło na moje życie”, co przecież dotyczyło następstw grania, a nie jego przyczyn. Powodem tego było najprawdopodobniej niezrozumienie polecenia, niedostateczne umiejętności autoanalizy lub wypowiedzi wynikające z młodego wieku badanych, pośpiechu itp. 
hobby, uprościć do trywialnego: „Bo lubią to”. Ów dosyć ogólny mianownik nie jest i nie mógłby się stać uniwersalną miarą ze względu na swój brak precyzyjności. Dlatego, aby nie wpadać w pułapkę statystyki - analizowania i grupowania odpowiedzi graczy i ich klasyfikacji w celu wyłonienia najbardziej ogólnych i uniwersalnych motywów ich działania - należy odwołać się do czegoś podstawowego, czegoś wcześniejszego niż sama wymiana.

Podstawowe założenie, jakie można poczynić względem człowieka, jest takie, że on działa. Uczynił tak ekonomista Ludwig von Mises, który zdefiniował ludzkie działanie jako wykazywanie zachowań celowych, czyli dążenie do celu. Polega ono jednocześnie na wyborze czegoś i rezygnacji z czegoś innego. Jest konsekwencją racjonalnej chęci człowieka do zamiany gorszego stanu na lepszy. Jej warunkami są jednak: uczucie dyskomfortu, wyobrażenie lepszego stanu rzeczy i przekonanie o możliwości jego osiągnięcia (Mises, 2011, s. 9-11). Te trzy elementy składają się na bardzo dobry opis stanu psychicznego, z jakim rozpoczyna rozgrywkę gracz cRPG i jaki powinien mu towarzyszyć, by gra nie traciła na swojej atrakcyjności.

Ideał ludzkiego działania można nazwać spełnieniem lub satysfakcją. Nic nie stoi na przeszkodzie, by spojrzeć na niego jako na coś stopniowalnego, wyznaczanego przez indywidualną oceną wartości na podstawie własnego osądu danego człowieka (tamże, s. 12). Ostatecznym bowiem celem ludzkiego działania jest zawsze zaspokojenie pragnień i choć zwykle tym pragnieniom nie ma końca, to przynajmniej częściowo ludzkie działanie powinno prowadzić do satysfakcji. Człowiek działa na wielu różnych polach i czerpie satysfakcję z różnych źródeł. Zatem co czyni akurat gry komputerowe obiektem ludzkiego działania?

Istnieją trzy najważniejsze cechy wyróżniające gry na tle innych rodzajów rozrywek. Pierwsza to wysoki poziom imersyjności, która oznacza doświadczenie silnego pochłonięcia przez aktywność lub środowisko (Skok, 2004). „Pochłonięcie przez środowisko” może jedynie dodatnio wpływać na intensyfikację potencjalnej wymiany. $Z$ tego m.in. powodu (obok wspomnianej jednoosobowej rozgrywki) wybrałem gry ulokowane w czterech wymienionych uniwersach. Są one bardzo dobrze oceniane przez graczy ${ }^{9}$ i uznałem to wskaźnik wysokiego poziomu ich

9 Średnia ocena ostatnich trzech tytułów z serii The Elder Scrolls, trylogii gier Mass Effect, Wiedźmin oraz pierwszych gier Gothic (z wyjątkiem trzeciej części, ocenianej 
imersyjności ${ }^{10}$. Drugą cechą gier wideo jest emersyjność - odwrotna do imersji, choć nie zawsze ją pomniejszająca. To efekt wynurzenia, uświadomienia sobie iluzyjności świata wirtualnego. Efekt ów powodują m.in. pewne uproszczenia poczynione w grze, jej schematyczność, pojawianie się interfejsu użytkownika czy celowy akt burzenia czwartej ściany (Kubiński, 2014). Trzecia cecha gier to - kluczowa dla tego artykułu - interaktywność, czyli zdolność do ustanawiania i podtrzymywania relacji z użytkownikiem (Wałaszewski, 2002). Właśnie ta cecha gier stała się podstawowym powodem, dla którego mogło być rozważane zachodzenie wymiany między graczem a światem wirtualnym. Jednak samo zbadanie istnienia tej relacji nie uprawnia do stwierdzenia, iż oparcie gier na zjawisku wymiany skutkuje dostarczaniem graczom satysfakcji. Dopiero udowodnienie konkretnego satysfakcjonującego wpływu tejże wymiany na graczy byłoby wystarczające. Dlatego następnym krokiem w kierunku weryfikacji postawionej hipotezy (już po uprzednim wykazaniu - dzięki udanemu użyciu teorii wymiany Homansa - że zjawisko wymiany może przynajmniej częściowo tłumaczyć fenomen gier komputerowych) jest zdefiniowanie uzyskiwanej przez graczy satysfakcji.

\section{Satysfakcja}

Na pytanie, czym jest satysfakcja, stara się odpowiedzieć psychologia pozytywna, której badania koncentrują się na poznaniu uzdolnień i sił charakteru poszczególnych ludzi. W przeciwieństwie do innych nurtów psychologii, skupiających się na wszelkiego rodzaju patologiach, psychologia pozytywna za cel obrała sobie odkrycie elementów, które

przeciętnie na 7,6/10) w serwisie IGN, GameSpot i GRY-Online.pl jest znacznie wyższa niż 8/10. Zob. sekcję Źródła ocen gier na końcu artykułu.

10 Po pierwsze, szczegółowa analiza imersji nie wydaje się potrzebna do osiągnięcia celu badania. Po drugie, w pełnym badaniu sprawdziłem (inspirując się Polskim Kwestionariuszem Imersji), czy we wskazanych grach gracze osiągają wysoki poziom imersji, i wynik był pozytywny. Po trzecie, imersja stanowi jedną ze składowych grywalności, rozumianej jako stopień dostarczania przez grę przyjemności i zabawy, który to stopień szacują gracze, wystawiając swoją ocenę. Por. González Sánchez; Gutiérrez Vela; Montero Simarro, Padilla-Zea. 
składają się na stan realnego szczęścia. Janusz Czapiński wyróżnia dwa nurty wewnątrz owej nauki -hedonistyczny i eudajmonistyczny (2004). Ten pierwszy można utożsamiać z badaniem subiektywnego oceniania użyteczności danego dobra czy działania. Natomiast charakterystyczną cechą podejścia eudajmonistycznego jest obecna w nim chęć stworzenia ogólnego schematu szczęśliwego człowieka oraz stronnicze (lecz oparte na ustaleniach aksjologii) określanie, na czym polega dobre życie ludzi. Obydwa nurty dobrze oddają sens psychologii pozytywnej, jednak to równoczesne wykorzystanie obydwu podejść w kontekście gier komputerowych powinno odnieść najlepszy skutek.

Granie w grę jest działaniem, a czynność ta często zajmuje wiele godzin i może wywierać pewien wpływ na człowieka, na jego generalne nastawienie do świata. Nastawienie czynnościowe to nic innego jak charakter, jedna z predyspozycji psychicznych według klasycznego ujęcia osobowości. Składają się nań tzw. siły charakteru. Według psychologów pozytywnych pomagają one w realizacji powszechnie uznawanych i docenianych wartości (Gulla, Tucholska, 2007, s. 135), co koresponduje z nurtem eudajmonistycznym, poszukującym uniwersalnego przepisu na szczęśliwe życie. Według statystycznych badań ankietowych (Park, Peterson, Seligman, 2004, s. 610) aby życie móc nazwać satysfakcjonującym, muszą być w nim obecne takie walory (siły) charakteru jak:

- nadzieja;

- zapał;

- ex aequo: miłość, ciekawość, wdzięczność.

Przez pryzmat tej hierarchii pięciu najwyższych sił charakteru można spojrzeć na zagadnienie satysfakcji w grach. Dzięki temu stanie się możliwe zbadanie wagi poszczególnych wartości składających się na „szczęśliwe życie” i - w duchu hedonistycznego nurtu psychologii pozytywnej - sprawdzenie, jakie znaczenie jest im przypisywane przez graczy.

\section{Wyniki badania satysfakcji}

Celem drugiej części badania było sprawdzenie, czy gry komputerowe wzmacniają w badanych pięć najważniejszych walorów charakteru: 
nadzieję, zapał, miłość, ciekawość, wdzięczność. Oznaczałoby to, że czynność grania w owe gry wzmacnia, stymuluje, dodatnio wpływa na satysfakcję odczuwaną w życiu człowieka, a nie tylko na chwilowe samopoczucie. Jeżeli odpowiedź byłaby pozytywna, to będzie można stwierdzić, iż gracze właśnie z tego powodu najbardziej pożądają wymiany w grach komputerowych - ponieważ jest ona dla nich korzystna. Odpowiedzi wszystkie pytania udzielano, wybierając na skali od 1 do 10, gdzie 1 oznaczało „Nigdy”, „W żadnym” itp., a 10 - „Bardzo często”, „Zawsze” itp., czyli w zależności od poglądu ankietowani umiejscawiali swoją reakcję w zakresie od jednoznacznie przeczącej (1) występowaniu danego zjawiska do jednoznacznie potwierdzającej (10) istnienie poszukiwanej prawidłowości.

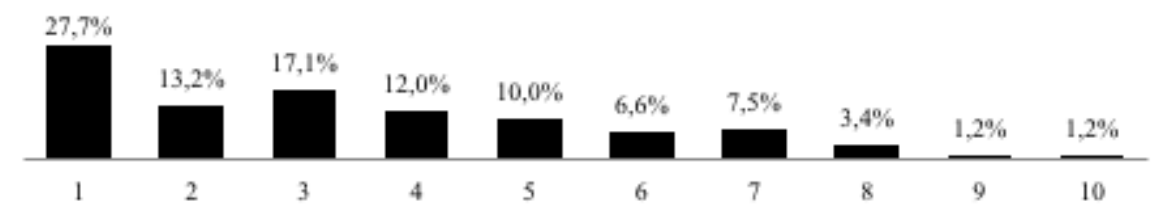

Wykres 9.1. Nadzieja: „Jak często traciłeś nadzieję na przejście danego etapu rozgrywki i na pewien czas przestawałeś grać w dany tytuł?"

Powyższe pytanie ma na celu sprawdzenie obecności nadziei u badanych - i stwierdzenie, czy gry osłabiały tę siłę charakteru, czy też pozwalały jej się rozwijać (przy założeniu istnienia takiej korelacji). Aż $80 \%$ graczy wskazało 5 lub mniej - czyli skłaniało się w różnym stopniu ku odpowiedzi „Nie traciłem/-am nadziei”.

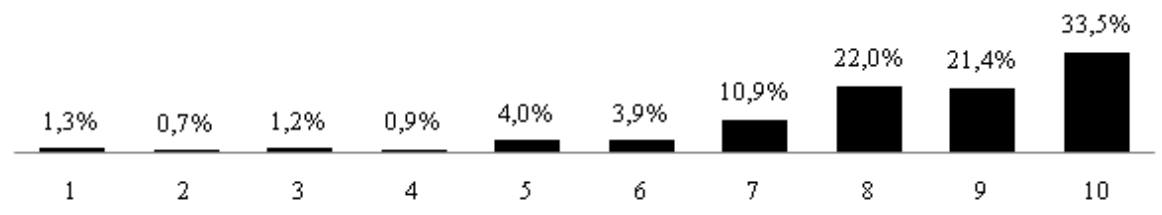

Wykres 9.2. Zapał: „Jak często podczas gry, mimo wielu nieudanych prób, nie rezygnowałeś/-aś, lecz z zapałem i determinacją podejmowałeś/-aś kolejne wysiłki, by osiągnąć zamierzony cel (np. pokonanie przeciwnika, zdobycie przedmiotu, dotarcie do danego miejsca)?" 
Jak można odczytać z wykresu 9.2, w odniesieniu do zapału aż 1/3 badanych przyznała 10 punktów, czyli stanowczą odpowiedź „Zawsze [z zapałem podejmowałem/-am kolejne wysiłki]", a 91,7\% ogółu oceniło odpowiedź na to pytanie na więcej niż 5 punktów. Utrata zapału występowała u graczy rzadziej niż utrata nadziei. Uprawnione wydaje się zatem stwierdzenie, że zapał był czymś ważniejszym, istotniejszym w procesie grania od nadziei.

Analizując przykłady wymienione przez uczestników badania, można wskazać cztery różne kierujące graczami motywacje stojące za zapałem. Je oraz ich bezpośrednie źródła przedstawia poniższa tabela.

Tabela nr 2. Motywacje graczy związane z zapałem

\begin{tabular}{c|c}
\hline $\begin{array}{c}\text { Podejmowanie } \\
\text { wyzwań }\end{array}$ & $\begin{array}{c}\text { gra w Dark Souls } \\
\text { gra w Counter Strike: Global Offensive }\end{array}$ \\
\hline Ciekawość & $\begin{array}{r}\text { celowe podwyższanie poziomu trudności w grze } \\
\text { wyuczona ciekawość na podstawie poprzednich gier } \\
\hline \text { Perfekcjonizm }\end{array}$ \\
\hline chęć poznania wszystkiego, co gra ma do zaoferowania \\
\hline wczytywanie poprzedniego stanu gry celem poprawiania się
\end{tabular}

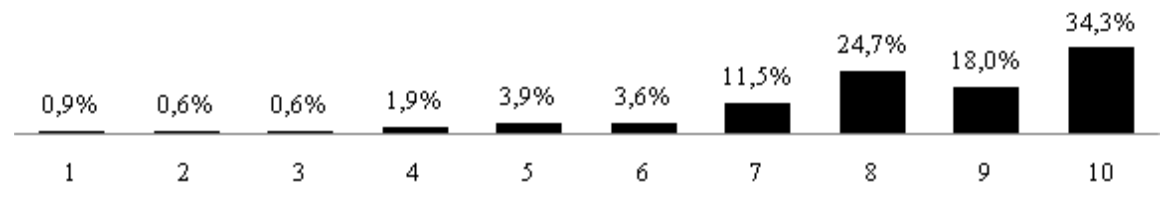

Wykres 9.3. Ciekawość: „W jakim stopniu Twoimi działaniami w grze kierowała ciekawość, chęć poznania świata przedstawionego?"

Na wykresie 9.3 widać, że wartość 10, najwyższą, przyznało 34,3\% ankietowanych, co jest równoznaczne $z$ traktowaniem przez nich ciekawości jako spiritus movens uczestniczenia w grze komputerowej, a precyzyjniej - w cRPG. Co najmniej 8 punktów przydzieliło w sumie $77 \%$, czyli ponad 3/4 badanych. Najczęstszymi myślami przewodnimi w uzasadnieniach graczy były:

- postrzeganie eksploracji, poznawania świata gry i jego historii za cel najwyższy; 
- zainteresowanie białymi plamami na mapie oraz „zakazanymi” obszarami;

- perfekcjonizm, chęć odkrycie wszystkich „znajdziek” oraz „smaczków".

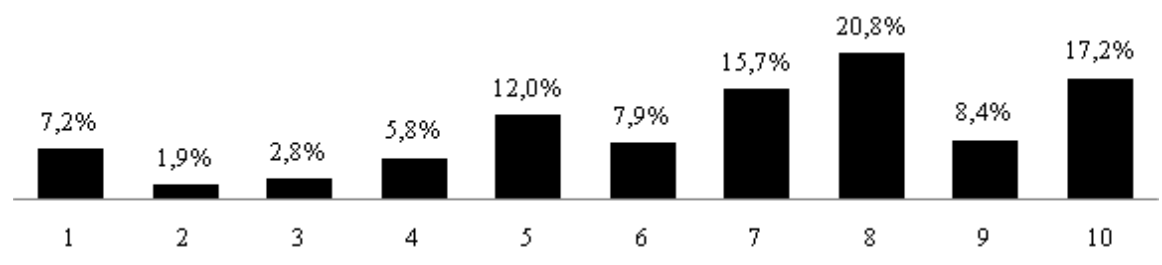

Wykres 9.4. Miłość: „Jak, Twoim zdaniem, obecność w grze wątków miłosnych (związanych z głównym protagonistą lub tylko bohaterami niezależnymi [NPCs]) wpłynęła na atrakcyjność gry?

Oceny znaczenia miłości w grze były najbardziej zróżnicowane na tle wszystkich pytań o 5 sił charakteru. Jak widać na Wykresie 9.4, znaczna większość wskazała jednak na dodatnią korelację tego aspektu z ogólną atrakcyjnością gry - 70\% graczy przyznało 6 i więcej punktów. Jako główne przyczyny swoich odpowiedzi wymieniali oni:

- wzbogacenie gry przez uobecnienie doznań zmysłowych o charakterze erotycznym, „krągłości”;

- zwiększenie imersji i uwiarygodnienie gry przez dodanie wątków miłosnych - takich jak w realnym życiu.

Pozostałe 30\% uznało obecność owych wątków za element bez znaczenia lub o niewielkiej wadze, określając go mianem „smaczku”. Część wskazywała na negatywne strony występowania tego typu motywów - wywoływać one mogą zazdrość dotyczącą (intymnego) życia fikcyjnych postaci.

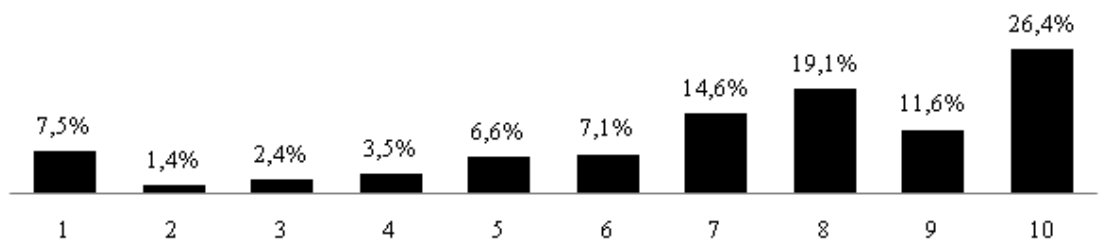

Wykres 9.5. Szacunek: „Jaki wpływ na satysfakcję z rozgrywki miało zdobywanie przez Twoją postać szacunku wśród bohaterów niezależnych?" 
Pytanie o szacunek miało za zadanie zbadać, jak ważny jest dla graczy element wdzięczności. Zgodnie z tym, co można odczytać z wykresu 9.5, aż 78,8\% ankietowanych wskazało 6 i więcej punktów, tym samym deklarując pozytywny wpływ szacunku, możliwości jego odczuwania, na atrakcyjność gry. Jako uzasadnienie swojej odpowiedzi wspominali oni najczęściej:

- wydłużenie gry przez uatrakcyjnienie fabuły dzięki temu elementowi (efektem było np. chętniejsze uczestnictwo w zadaniach pobocznych);

- możliwość lepszego poznania postaci w grze i zawiązania bliższej relacji z nimi;

- efekt motywacyjny;

- nieznaczny wzrost dobrego samopoczucia i samooceny przez bycie docenianym i rozpoznawanym w wirtualnym świecie;

- lepsze „wczucie się”, większa imersja dzięki lepszemu odzwierciedleniu rzeczywistości.

\section{Wnioski z badania satysfakcji}

Wnioski, które zaraz zostaną przedstawione, powinny być odczytywane w świetle założeń, jakie przyjąłem: po pierwsze, że sformułowane przeze mnie pytania dotyczące każdego z walorów charakteru w sposób wystarczający badają ich występowanie; po drugie, że obecność tych wartości w świecie wirtualnym jest równoznaczna z ich obecnością w życiu graczy, czyli że świat wirtualny i świat realny są komponentami ich rzeczywistości. Nie orzekam tutaj o tym, czy w przypadku np. miłości jej pojawienie się w grze przekłada się na większy lub mniejszy stopień kochliwości lub popędu gracza w świecie realnym. Jednakże próba zbadania tego typu korelacji, związanej z nadzieją, zapałem, miłością, ciekawością, wdzięcznością i ich różnymi formami, byłaby niewątpliwie interesująca.

Na podstawie wyników badań można stwierdzić, iż gry rzeczywiście wzmacniają pięć najwyższych sił charakteru, stymulują je czy też dodatnio wpływają na nie. Jednak nie czynią tego w standardowej hierarchii, co też prezentuje tabela na kolejnej stronie. 
Tabela 3. Ranking sił charakteru

\begin{tabular}{cccc} 
Miejsce & $\begin{array}{c}\text { Siły charakteru } \\
\text { w świecie realnym }\end{array}$ & $\begin{array}{c}\text { Siły charakteru w świecie } \\
\text { wirtualnym (zmiana pozycji) }\end{array}$ & $\begin{array}{c}\text { Średnia arytmetyczna } \\
\text { odpowiedzi badanych }\end{array}$ \\
\hline 1 & Nadzieja & Ciekawość (+2) & 8,35 \\
\hline 2 & Zapał & Zapał (0) & 8,34 \\
\hline 3 & Ciekawość & Nadzieja (-2) & 7,54 \\
\hline 4 & Wdzięczność & Wdzięczność (0) & 7,29 \\
\hline 5 & Miłość & Miłość $(0)$ & 6,76 \\
\hline
\end{tabular}

W porównaniu do przytoczonej hierarchii pięciu najwyższych sił charakteru najbardziej na znaczeniu w grach straciła nadzieja, z pierwszego miejsca spadając na trzecie, a najwięcej zyskała ciekawość, awansując z trzeciego miejsca na pierwsze i właściwie dzieląc je z zapałem (który zajmuje drugą pozycję tylko przez różnicę o,o1 punktu). Na trzecim miejscu znalazła się nadzieja, na czwartym - niewiele mniej od niej ważna wdzięczność. Ten ostatni walor charakteru może odgrywać jeszcze większą rolę, niż wskazywałoby niniejsze badanie, dobrowolna wymiana bowiem, rozumiana jako gra o sumie dodatniej, czyli taka, w której każdy odnosi korzyść i brak jest „przegranej” czy „poszkodowanej” strony, zdaje się naturalnie skutkować poczuciem wdzięczności. Zdecydowanie najgorzej wypadła miłość.

Różnica w powyższych rankingach potwierdza to, co podpowiada intuicja: świat wirtualnej rozrywki - nawet tak bardzo rozbudowany jak w komputerowych grach fabularnych - nie jest w stanie samodzielnie zapewnić człowiekowi szczęścia. Takie wartości jak nadzieja czy miłość są w nim niedowartościowane, do czego zapewne przyczynia się pewne niezależne od stopnia immersji i zaangażowania w grę - poczucie nieprawdziwości, czegoś tymczasowego i rządzącego się swoimi prawami (Huizinga, 2007, s. 21), czyli coś zbliżonego do części przyczyn emersji. Gry najlepiej generują i zaspokajają ciekawość i zapał.

\section{Podsumowanie}

Hipotezę badawczą tego artykułu, mówiącą, że gry komputerowe są oparte na zjawisku wymiany, co skutkuje dostarczaniem graczom satysfakcji, 
można uznać za potwierdzoną. Gracze decydują się zakupić grę - według nich - z uwagi na samą satysfakcję, wymiana (własnego czasu) stanowi zaś co najmniej środek do jej osiągnięcia. Należy pamiętać, iż przynależną ludziom skłonność stanowi właśnie wymiana, w istocie będąca pośrednim - zazwyczaj nieuświadomiony - celem ich działań. Nie można jej uznać za cel bezpośredni, ponieważ gracze, pisząc uzasadnienia dla własnych odpowiedzi, zwykle nie zwracali uwagi na drugi podmiot wymiany, np. na grę, komputer, twórców gry czy protagonistę.

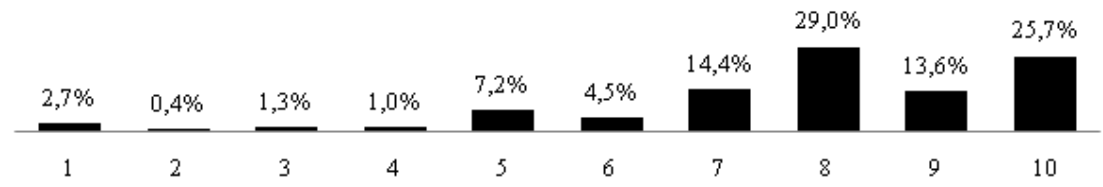

Wykres 11. Ocena twierdzenia "Granie w gry komputerowe pozytywnie wpłynęło na moje życie"

Z informacji zamieszczonych na Wykresie 11 wynika, że dla znacznej większości granie w gry komputerowe pozytywnie wpłynęło na ich życie - tak orzekło 87,2\%, wskazując wartości 6 i większe. Podane przez nich przykłady dodatniego oddziaływania na ich życie były bardzo zróżnicowane, jednak można je zakwalifikować do czterech grup odpowiedzi.

\begin{tabular}{|c|c|}
\hline \multirow{3}{*}{$\begin{array}{l}\text { Kompetencje } \\
\text { twarde }\end{array}$} & zyskanie wiedzy \\
\hline & pogłębienie znajomości języka angielskiego \\
\hline & lepsze zarządzanie pieniędzmi \\
\hline \multirow{5}{*}{$\begin{array}{l}\text { Kompetencje } \\
\text { miękkie }\end{array}$} & nauka cierpliwości i wytrwałości \\
\hline & wzrost refleksu \\
\hline & rozwój wyobraźni oraz logicznego i strategicznego myślenia \\
\hline & zwiększenie decyzyjności i umiejętności analizowania \\
\hline & lepsza komunikatywność \\
\hline \multirow{7}{*}{$\begin{array}{l}\text { Rozwój } \\
\text { osobisty }\end{array}$} & przeżycie interesujących przygód \\
\hline & nowe zainteresowanie, pasja \\
\hline & wzrost samooceny \\
\hline & nowi znajomi \\
\hline & wyrobienie charakteru i poglądów \\
\hline & wyznaczenie celu kariery \\
\hline & zainteresowanie fantastyką \\
\hline
\end{tabular}




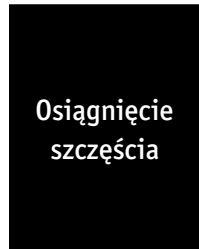

dobra zabawa

możliwość odpoczynku

ucieczka od ponurej rzeczywistości

poznanie swojego partnera życiowego dzięki wspólnej pasji

odnalezienie powołania i zostanie programistą

Zjawisko gier komputerowych bazuje na wymianie gracz-gra, której przedmiotem jest satysfakcja wyrażana w różnych pozytywnych efektach. Wymiana ta - dzięki pomyślnemu zastosowaniu teorii Homansa - może zostać uznana zarówno za socjologiczną, jak i ekonomiczną. Ma ona jednak charakter pośredni, ponieważ żaden $\mathrm{z}$ badanych samodzielnie nie wskazał drugiego (oprócz nich samych) podmiotu wymiany.

\section{Literatura}

Czapiński, J. (red.). (2004). Psychologia pozytywna. Nauka o szczęściu, zdrowiu, sile i cnotach człowieka. Warszawa: Wydawnictwo Naukowe PWN. González Sánchez, J. L., Gutiérrez Vela, F. L., Montero Simarro, F., Padilla-Zea, N. (2012). Playability: analysing user experience in video games. BehaviourE Information Technology, 31(10): 1033-1054. Online: <http:// www.tandfonline.com/doi/full/10.1080/0144929X.2012.710648>.

Homans, G. C.(1992). Podstawowe procesy społeczne. (tłum. J. Olbrycht). W: M. Kempny M., Szmatka J. (red.), Współczesne teorie wymiany społecznej. Warszawa: Wydawnictwo Naukowe PWN.

Huizinga, J. (2007). Homo ludens. Zabawa jako źródło kultury (tłum. M. Kurecka, W. Wirpsza. Warszawa: Aletheia.

Kubiński, P. (2014). Emersja - antyiluzyjny wymiar gier wideo. Nowe Media, 5 (4). McDonald, E. (20 kwietnia 2017). The Global Games Market Will Reach $\$ 108.9$ Billion in 2017 With Mobile Taking 42\%. Online: <http://newzoo. com/insights/articles/the-global-games-market-will-reach-108-9-billion-in-2017-with-mobile-taking-42>. Data dostępu: 6 grudnia 2017.

Mises, L. von (2011). Ludzkie działanie. Traktat o ekonomii (tłum. W. Falkowski). Warszawa: Instytut Ludwiga von Misesa.

Park, N., Peterson, C., Seligman M. E. P. (2004). Strenghts of character and well-being. Journal of Social and Clinical Psychology, 23(5). 
Skok, K. (2014). Wykorzystanie rzeczywistości wirtualnej w grach. Wnioski z badań nad iluzją gumowej ręki i obecnością. Homo Ludens, 6(1).

Smith, A. (1776). An Inquiry into the Nature and Causes of the Wealth of Nations. Online: <http://econlib.org/library/Smith/smWN1.html>. Data dostępu: 28 września 2017.

Szacki, J. (2007). Historia myśli socjologicznej. Wydanie nowe. Warszawa: Wydawnictwo Naukowe PWN.

Walków, M. (14 maja 2018). Pokolenie na rynku pracy w Polsce - kim są baby boomers X, Y, C? Online: <http://businessinsider.com.pl/ rozwoj-osobisty/kariera/millenials-pokolenie-x-y-z-i-baby-boomers-kim-sa-na-rynku-pracy/6e53lmr>. Data dostępu: 6 grudnia 2017.

Wałaszewski, Z. (2002). Interaktywność gier komputerowych. W: M. Hopfinger (red.), Nowe media w komunikacji społecznej $w$ XX wieku. Antologia. Warszawa: Oficyna Naukowa.

Winnicki, Ł. (2017). Rola wymiany w grach komputerowych w Polsce. Kraków: niepublikowana praca licencjacka.

Worldometers.com. Światowa populacja. Online: <http://www.worldometers.info/pl>. Data dostępu: 6 grudnia 2017.

\section{Źródta ocen gier}

IGN Polska. The Witcher. Online: <http://www.ign.com/games/the-witcher>.

IGN Polska. The Witcher 2: Assassins Of Kings. Online: <http://www.ign. com/games/the-witcher-2-assassins-of-kings>.

IGN Polska. Wiedźmin 3: Dziki Gon. Online: <http://www.ign.com/games/ the-witcher-3>.

IGN. Gothic. Online: <http://www.ign.com/games/gothic>.

IGN. Gothic 2. Online: <http://www.ign.com/games/gothic-2>.

IGN Polska. Mass Effect. Online: <http://www.ign.com/games/masseffect>.

IGN Polska. Mass Effect 2. Online: <http://www.ign.com/games/masseffect-2>.

IGN Polska. Mass Effect 3. Online: <http://www.ign.com/games/masseffect-3>.

IGN Polska. The Elder Scrolls III: Morrowind. Online: <http://www.ign.com/ games/the-elder-scrolls-iii-morrowinds. 
IGN Polska. The Elder Scrolls IV: Oblivion. Online: <http://www.ign.com/ games/the-elder-scrolls-iv-oblivion>.

IGN Polska. The Elder Scrolls V: Skyrim. Online: <http://www.ign.com/ games/the-elder-scrolls-v-skyrim>.

GryOnline.pl. Wiedźmin PC. Online: <http://www.gry-online.pl/gry/the-witcher/zo1348>.

GryOnline.pl. Wiedźmin 2: Zabójcy Królów. Online: <http://www.gry-online.pl/gry/the-witcher-2-assassins-of-kings/zf384>.

GryOnline.pl. Online: <http://www.gry-online.pl/gry/the-witcher-3-wild-hunt/z83579>.

GryOnline.pl. Wiedźmin 3: Dziki Gon. Online: <http://www.gry-online.pl/ gry/gothic/z11394>.

GryOnline.pl. Gothic II PC. Online: <http://www.gry-online.pl/gry/gothic-ii/zc1065>.

GryOnline.pl. Mass Effect. Online: <http://www.gry-online.pl/gry/mass-effect/z9801>.

GryOnline.pl. Mass Effect 2 PC. Online: <http://www.gry-online.pl/gry/ mass-effect-2/z39f4\#pc $>$.

GryOnline.pl. Mass Effect 3. Online: <http://www.gry-online.pl/gry/mass-effect-3/z4569>.

GryOnline.pl. The Elder Scrolls III: Morrowind. Online: <http://www.gry-online.pl/gry/the-elder-scrolls-iii-morrowind/z4112>.

GryOnline.pl. The Elder Scrolls IV: Oblivion PC. Online: <http://www.gry-online.pl/gry/the-elder-scrolls-iv-oblivion/zf258\#pc>.

GryOnline.pl. The Elder Scrolls V: Skyrim PC. Online: <http://www.gry-online.pl/gry/the-elder-scrolls-v-skyrim/z923d\#pc>.

GameSpot. The Witcher. Online: <http://www.gamespot.com/the-witcher>.

GameSpot. Online: The Witcher 2: Assassins of Kings. Online: <http://www. gamespot.com/the-witcher-2-assassins-of-kings>.

GameSpot. Online: The Witcher 3: Wild Hunt. Online: <http://www.gamespot.com/the-witcher-3-wild-hunt>.

GameSpot. Gothic. Online: <http://www.gamespot.com/gothic>.

GameSpot. Gothic II. Online: <http://www.gamespot.com/gothic-ii $>$.

GameSpot. Mass Effect. Online: <http://www.gamespot.com/mass-effect>.

GameSpot. Mass Effect 2. Online: <http://www.gamespot.com/mass-effect-2>. 
GameSpot. Mass Effect 3. Online: <http://www.gamespot.com/mass-effect-3>.

GameSpot. The Elder Scrolls III: Morrowind. Online: <http://www.gamespot. com/the-elder-scrolls-iii-morrowinds.

GameSpot. The Elder Scrolls IV: Oblivion. Online: <http://www.gamespot. com/the-elder-scrolls-iv-oblivion>.

GameSpot. The Elder Scrolls V: Skyrim. Online: <http://www.gamespot. com/the-elder-scrolls-v-skyrim>.

Data dostępu do źródeł wymienionych w tej sekcji: 19 marca 2017.

lic. Łukasz Winnicki - student studiów uzupełniających magisterskich na kierunku ekonomia na Uniwersytecie Ekonomicznym w Krakowie. Absolwent Wydziałowej Indywidualnej Ścieżki Edukacyjnej (WISE)

\title{
Co jest źródłem satysfakcji gracza? 0 kluczowej roli wymiany autystycznej w grach komputerowych
}

\begin{abstract}
Abstrakt: Artykuł omawia możliwość opisania i wytłumaczenia zjawiska gier komputerowych za pomocą bardziej pierwotnego fenomenu - wymiany. Autor, korzystając z myśli ekonomisty Ludwiga von Misesa, nazywa czynność grania wymianą autystyczną i za pomocą socjologicznej teorii wymiany George'a Homansa sprawdza, czy gry komputerowe są oparte na zjawisku wymiany, co skutkuje dostarczaniem graczom satysfakcji. W tym celu przytoczonych zostaje pięć najwyższych sił charakteru warunkujących szczęśliwe życie. W wyniku przeprowadzonego na 669 osobach badania kwestionariuszowego hipoteza badawcza zostaje zweryfikowana pozytywnie.
\end{abstract}

Słowa kluczowe: gra wideo, wymiana, George Homans, Ludwig von Mises, satysfakcja, siły charakteru 